\title{
Manajemen Lembaga Pendidikan Berorientasi Mutu Di MA Sunan Pandanaran Yogyakarta
}

\author{
Safinah \\ Safinah01almubarrok@gmail.com \\ Institut Agama Islam Hamzanwadi NW Lombok Timur, Indonesia
}

\begin{abstract}
Abstrak
Madrasah Aliyah Sunan Pandanaran ini merupakan lembaga pendidikan yang sangat dikenal baik di Yogyakarta maupun Luar Yogyakarta. Selain itu, MA Sunan Pandanaran mempunyai beberapa program layanan pendidikan dan kerja sama dengan berbagai lembaga pendidikan. Dengan kemampuan MA Sunan ini menunjukkan bahwa Manajemen Mutu di lembaga pendidikan tersebut dikelola dengan baik. Penelitian ini bertujuan untuk mengetahui bagaimana lembaga pendidikan Islam yang berorientasi pada Mutu Pendidikan. Penelitian ini termasuk ke dalam jenis penelitian lapangan (field research) dengan pendekatan kualitatif. Peneliti mencoba menganalisis pengelolaan lembaga Pendidikan Islam yang berorientasi pada mutu pendidikan pesantren. Teknik pengumpulan data dapat dilakukan dengan Observasi (pengamatan), Interview (wawancara), dan Dokumentasi Gabungan ketiganya. Sistem pengendalian mutu MA sunan pandanaran dilakukan melalui Sumber Daya Manusia dengan mengadakan Teaching training center dan ada beberapa kegiatan yang di lakukan dalam sistem pengendalian mutu, yaitu: Mengadakan breffing pagi sebelum masuk ke kelas jam pertama, Setiap akhir bulan mengadakan evaluasi kurikulum pembelajaran, Wali kelas, tenaga pendidik, guru mapel melakukan evaluasi sikap dan pengetahuan peserta didik. Sistem evaluasi MA Sunan pandanaran yaitu ada beberapa mekanisme yang dilakukan yaitu dari program monitoring dan evaluasi yang menyangkut: penyusunan rencana monitoring untuk setiap kegiatan, Melaksanakan monitoring dan evaluasi penyelenggaraan pendidikan, Menyusun Laporan, Tindak Lanjut Monitoring dan Evaluasi.
\end{abstract}

Kata Kunci: Manajemen, Lembaga Pendidikan, Mutu

\section{Pendahuluan}

Perubahan dalam lembaga pendidikan adalah suatu keharusan, mampu mendorong perubahan dari dalam organisasi itu sendiri seperti permasalahan Sumber Daya Manusia (SDM), dan keputusan atau perilaku dari manajerial. Namun tidak kalah penting juga pendorong perubahan ini yaitu kemajuan teknologi, perubahan pasar, dan tekanan sosial politik.Hal ini akan berdampak pada kualitas dan mutu pendidikan tersebut, setiap lembaga pendidikan dikatakan berkualitas dan 
Jurnal manajemen dan budaya STAI Darul Kamal NW Kembang kerang

Volume 1 No 2 Tahun 2021

P-ISSN : 2775-1643

E-ISSN : 2774-6704

https://journal.staidk.ac.id/index.php/manajemenbudaya

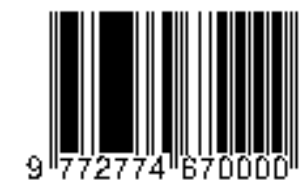

bermutu apabila mampu memenuhi kebutuhan yang ada dilembaganya, baik dari sumber daya dan kepuasan para pelanggan pendidikan.

Bagi setiap institusi termasuk lembaga pendidikan, mutu adalah agenda utama dan meningkatkan mutu merupakan tugas yang paling penting, karena dalam sebuah organisasi atau lembaga pendidikan tentu mempunyai tujuan, visi dan misi yang menjadi target pencapaian dalam mengerjakan suatu pekerjaan. Untuk mencapai semua itu harus melalui serangkaian proses yakni; perencanaan program, implementasi program, hingga sampai tahapan evaluasi hasil pelaksanaan program yang terstruktur dengan jelas dan rapi yang merupakan prinsip manajemen.

Kualitas dan mutu yang sangat bervariatif, menyebabkan persaingan yang sangat kompetitif. Setiap lembaga pendidikan berusaha secara maksimal untuk meningkat kualitas pendidikan dengan menciptakan inovasi secara profesional, guna mendapatkan mutu pendidikan yang tinggi. Mutu dan kualitas pendidikan juga tidak lepas dari visi misi yang di rumuskan, karena visi dan misi merupakan pijakan untuk menuju kepada pencapaian tujuan pendidikan.

Hasil pendidikan dipandang bermutu jika mampu melahirkan keunggulan akademik dan ekstrakurikuler pada peserta didik yang dinyatakan lulus untuk satu jenjang pendidikan atau menyelesaikan program pembelajaran tertentu. Mutu sebuah sekolah juga dapat dilihat dari tertib administrasinya. Salah satu bentuk tertib administrasi adalah adanya mekanisme kerja yang efektif dan efisien, baik secara vertikal maupun horizontal. ${ }^{1}$

Mutu pendidikan itu tidak hanya diukur dari mutu keluaran pendidikan secara utuh (educational outcomes), dan itu dikaitkan dengan konteks di mana mutu itu ditempatkan dan berapa besar persyaratan tambahan yang diperlukan untuk itu. Mutu pendidikan juga dapat diukur dari besarnya kapasitas layanan pendidikan dalam memenuhi customers needs and wants. Jika dilihat dari sudut pandang ekonomi,

1 Sudarwan Danim, Visi Baru Manajemen Sekolah (Dari Unit Birokrasi ke Lembaga Akademik), (Jakarta: PT Bumi Aksara, 2006). 
Jurnal manajemen dan budaya STAI Darul Kamal NW Kembang kerang

Volume 1 No 2 Tahun 2021

P-ISSN : 2775-1643

E-ISSN : 2774-6704

https://journal.staidk.ac.id/index.php/manajemenbudaya

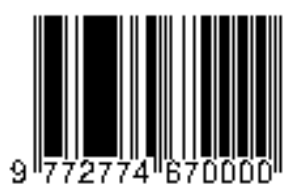

maka mutu pendidikan dapat diukur dari besarnya earnings yang diperoleh oleh lulusan setelah menyelesaikan jenjang pendidikan tertentu. ${ }^{2}$

Terkait dengan hal tersebut, konstruksi kualitas pada sebuah sekolah/madrasah tidak bisa dilepaskan dari peran dua hal, yaitu: pertama, pengelola sekolah/madrasah yang berfungsi untuk mengkonstruksi sistem pendidikan secara inheren dalam proses pendidikan melalui upaya penjamin mutu dengan menciptakan sistem manajemen pendidikan secara aplikatif dan sistematis. ${ }^{3}$ Kedua, pemerintah, yang bertanggung jawab mengkonstruksi istem pendidikan untuk menentukan standar kualitas pendidikan secara general berdasarkan level-level kualitas yang ditentukan melalui proses kegiatan penilaian kelayakan program dan satuan pendidikan berdasarkan kriteria yang ditetapkan untuk menjamin mutu pendidikan sekolah/madrasah. ${ }^{4}$

Sebagai salah satu lembaga yang mencetak generasi islami, madrasah juga dituntut untuk menjaga kualitas dan berkomitmen terhadap mutu lembaganya. Dalam hal ini, MA Sunan Pandanaran diharapkan mampu mewakili lembaga pendidikan untuk lebih eksis dan mampu menguasai dunia pendidikan. Mutu dan kualitas dari MA Sunan Pandanaran menjadi tolak ukur bagi masyarakat dalam memilih jenjang pendidikan. Pendidikan yang bermutu akan menghasilkan output yang lebih berkualitas dan mampu mempersiapkan generasi muda yang berani bersaing dengan generasi muda dari negara lain.

Penelitian ini difokuskan pada manajemen pendidikan yang berorientasi mutu di MA Sunan Pandanaran. MA Sunan Pandanaran menjadi tempat penelitian karena MA Sunan Pandanaran ini merupakan lembaga pendidikan yang sangat dikenal baik di Yogyakarta maupun Luar Yogyakarta. Selain itu, MA Sunan Pandanaran ini mempunyai beberapa program layanan pendidikan dan kerjasama dengan berbagai lembaga, baik dalam maupun luar negeri. Dari segi keragaman peminat, MA Sunan 2003).

2 Sudarwan Danim, Agenda Pembaruan Sistem Pendidikan, (Yogyakarta: Pustaka Pelajar,

${ }^{3}$ E.A. Kuncoro, dalam Buchori Alma (ed), Manajemen Coorporate Strategi Pemasaran Jasa Pendidikan : Fokus Mutu dan Layanan Prima, (Bandung, Alfabeta, 2008)

4 Peraturan Menteri Pendidikan dan Kebudayaan Nomor 59 tahun 2012 tentang Badan Akreditasi Nasional 
Jurnal manajemen dan budaya STAI Darul Kamal NW Kembang kerang

Volume 1 No 2 Tahun 2021

P-ISSN : 2775-1643

E-ISSN : 2774-6704

https://journal.staidk.ac.id/index.php/manajemenbudaya

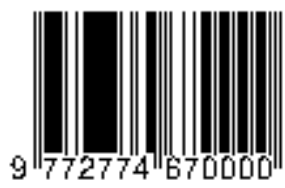

Pandanaran tidak bersifat eksklusif, akan tetapi berbagai lapisan masyarakat dari berbagai wilayah dan suku yang ada di Indonesia yang hidup dalam kebersamaan. Harapan untuk mewujudkan generasi penerus bangsa Indonesia yang saling memahami dan bekerjasama, meski dengan latar belakang etnik, bahasa, dan budaya yang berbeda-beda menjadi harapan masa depan bangsa dalam menghadapi realita sosial-budaya di era industry 4.0 dapat terealisasi dari lembaga pendidikan dengan kualitas yang ideal. Oleh karena itu, menjadikan MA Sunan Pandanaran sebagai tempat penelitian adalah pilihan yang sangat tepat.

\section{Kajian Pustaka}

Konsep manajemen mutu Menurut Pleffer dan Coote dikutip oleh Aan Komariah, secara esensial istilah mutu menunjukkan kepada sesuatu ukuran penilaian atau penghargaan yang diberikan atau dikenakan kepada barang (products) dan kinerjanya. ${ }^{5}$ Selanjutnya pendapat B. Suryobroto yang menyebutkan bahwa konsep mutu mengandung pengertian makna derajat (tingkat) keunggulan satu produk (hasil kerja/upaya) baik berupa barang maupun jasa, baik yang tangible maupun intangible. ${ }^{6}$ Mutu adalah ukuran baik-buruk suatu benda; kadar; taraf atau derajat (kepandaian, kecerdasan, dan sebagainya). sehingga pada dasarnya manajemen mutu dapat didefinisikan sebagai suatu cara meningkatkan performance secara terus-menerus (continous performance improvement) pada setiap level operasi atau proses, dalam setiap area fungsional dari suatu organisasi, dengan menggunakan semua SDM dan modal yang tersedia. ${ }^{7}$

Dalam pendidikan, mutu adalah suatu keberhasilan proses belajar yang menyenangkan dan memberikan kenikmatan. Pelanggan bisa berupa mereka yang langsung menjadi penerima produk dan jasa tersebut atau mereka yang nantinya

${ }^{5}$ Aan Komariyah dan Cepi Triatna, Visonary Leadership; Menuju Sekolah Efektif (Jakarta: Bumi Aksara, 2008).

${ }^{6}$ B. Suryobroto, Manajemen Pendidikan di Sekolah (Jakarta: Rineka Cipta, 2004).

7 Vincent Gaspersz, Total Quality Management, (Jakarta: PT Gramedia Pustaka Utama, 2001). 
Jurnal manajemen dan budaya STAI Darul Kamal NW Kembang kerang

Volume 1 No 2 Tahun 2021

P-ISSN : 2775-1643

E-ISSN : 2774-6704

https://journal.staidk.ac.id/index.php/manajemenbudaya

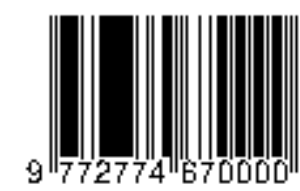

akan merasakan manfaat produk dan jasa tersebut. ${ }^{8}$ Mutu adalah kemampuan (ability) yang dimiliki oleh suatu produk atau jasa (service)yang dapat memenuhikebutuhan atau harapan, kepuasan (satisfaction) pada pelanggan (customers). ${ }^{9}$

Syaiful Sagala menyebutkan bahwa mutu pendidikan adalah gambaran dan karakteristik menyeluruh jasa pelayanan pendidikan secara internal dan eksternal yang menunjukkan kemampuannya, memuaskan kebutuhan yang diharapkan, atau yang tersirat mencakup input, proses, dan output pendidikan. ${ }^{10}$

Pertama: Input pendidikan lembaga pendidikan yang efektif dalam rangka meningkatkan mutu pelayanan pendidikan setidaknya memiliki berbagai karakteristik diantaranya adalah, (1) Memiliki kebijakan, tujuan dan sasaran mutu yang jelas; (2) Sumberdaya tersedia dan siap; (3) Staf yang kompeten dan berdedikasi tinggi; (4) Memiliki harapan prestasi yang tinggi; (5) Fokus pada pelanggan (khususnya siswa); (6) Input manajemen.

Kedua: Proses pendidikan lembaga pendidikan yang efektif pada umumnya memiliki sejumlah karakteristik proses sebagai berikut, (1) Proses belajar mengajar yang efektifitasnya tinggi; (2) Kepemimpinan lembaga pendidikan yang kuat; (3) Lingkungan lembaga pendidikan yang aman dan tertib; (4) Pengelolaan tenaga kependidikan yang efektif; (5) Lembaga pendidikan memiliki budaya mutu; (6) Lembaga pendidikan memiliki "Teamwork" yang kompak, cerdas, dan dinamis; (7) Lembaga Pendidikan Islam memiliki kewenangan (kemandirian); (8) Partisipasi yang tinggi dari warga dan masyarakat; (9) Lembaga pendidikan memiliki keterbukaan (transparansi) manajemen; (10) Lembaga pendidikan memiliki kemauan untuk berubah (psikologis dan pisik); (11) Lembaga pendidikan melakukan evaluasi dan perbaikan secara berkelanjutan; (12) Lembaga pendidikan responsif dan antisipatif terhadap kebutuhan; (13) Memiliki komunikasi yang baik; (14) Lembaga pendidikan

${ }^{8}$ Ravik Karsidi, Peningkatan Mutu Pendidikan Melalui Penerapan Teknologi Belajar Jarak Jauh, Makalah Disampaikan dalam Seminar Regional Unit Pelaksana Belajar Jarak Jauh Universitas Terbuka, Solo: 28 Mei 2005.

${ }_{9}$ Nanang Fattah, Sistem Penjaminan Mutu Pendidikan, (Bandung: Remaja Rosda Karya, 2012).

10 Syaiful Sagala, Manajemen Mutu Terpadu dalam Pendidikan; Konsep, Strategi dan Aplikasi (Jakarta: PT Grasindo, 2002). 
Jurnal manajemen dan budaya STAI Darul Kamal NW Kembang kerang

Volume 1 No 2 Tahun 2021

P-ISSN : 2775-1643

E-ISSN : 2774-6704

https://journal.staidk.ac.id/index.php/manajemenbudaya

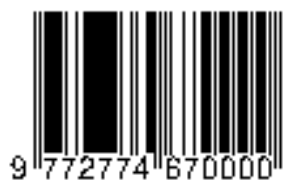

memiliki akuntabilitas; (15) Lembaga pendidikan memiliki kemampuan manajemen sustainbilitas.

Ketiga: Output Lembaga pendidikan adalah prestasi yang dihasilkan oleh proses pembelajaran dan manajemen di lembaga pendidikan. Pada umumnya, output dapat diklasifikasikan menjadi dua, yaitu output berupa prestasi akademik (academic achivement): Output prestasi akademi misanya, NEM, lomba karya ilmiah remaja, lomba (Bahasa Inggris, Matematika, Fisika), cara-cara berfikir (kritis, kreatif/divergen, nalar, rasional, induktif, deduktf, dan ilmiahdan ouput berupa prestasi non-akademik (non-academic achivement).): Output non-akademik, misalnya keingintahuan yang tinggi,

Proses pendidikan bermutu apabila mampu menciptakan suasana yang PAKEMB (Pembelajaran yang Aktif, Kreatif, Menyenangkan, dan Bermakna). Output, dinyatakan bermutu jika hasil belajar akademik dan non akademik siswa tinggi. Outcome, dinyatakan bermutu apabila lulusan cepat terserap di dunia kerja, gaji wajar, semua pihak mengakui kehebatan lulusan dan merasa puas. ${ }^{11}$

\section{Standar Nasional Pendidikan}

Standar mutu adalah seperangkat tolok ukur kinerja sistem pendidikan yang mencakup masukan, proses, hasil, keluaran serta manfaat pendidikan yang harus dipenuhi oleh unit-unit kerja. Di Indonesia, standar mutu sebuah produk diterbitkan oleh BSN (Badan Standarisasi Nasional) merupakan Lembaga Pemerintah Non Kementerian dengan tugas pokok mengembangkan dan membina kegiatan standarisasi di Indonesia, termasuk metrology, standar, pengujian dan mutu. Dalam melaksanakan tugasnya, BSN berpedoman pada Peraturan Pemerintah No. 102 Tahun 2000 tentang Standarisasi Nasional.

SNP adalah kriteria minimal tentang sistem pendidikan di seluruh wilayah hukum Negara Kesatuan Republik Indonesia. Oleh karena itu, SNP harus dijadikan acuan guna memetakan secara utuh profil kualitas sekolah/madrasah. Di dalam pasal 2 ayat 1, lingkup SNP meliputi: (1) standar isi; (2) standar proses; (3) standar

11 Husaini Usman,Manajemen: Teori, Praktik, dan Reset Pendidikan, (Jakarta: Bumi Aksara, 2009). 
Jurnal manajemen dan budaya STAI Darul Kamal NW Kembang kerang

Volume 1 No 2 Tahun 2021

P-ISSN : 2775-1643

E-ISSN : 2774-6704

https://journal.staidk.ac.id/index.php/manajemenbudaya

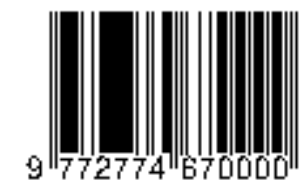

kompetensi lulusan; (4) standar pendidik dan tenaga kependidikan; (5) standar sarana dan prasarana; (6) standar pengelolaan; (7) standar pembiayaan; dan (8) standar penilaian pendidikan.

Standar mutu berdasarkan pada Peraturan Pemerintah No. 32 tahun 2013 tentang Standar nasional Pendidikan (SNP) yang terdiri dari 8 standar, yaitu: pertama; Standar Kompetensi Lulusan: Standar kompetensi lulusan adalah kualifikasi kemampuan lulusan yang mencakup sikap, pengetahuan,dan ketrampilan. ${ }^{12}$ Kedua; Standar Isi meliputi ruang lingkup materi dan tingkat kompetensi yang dituangkan dalam kriteria tentang kompetensi tamatan, kompetensi bahan kajian, kompetensi mata pelajaran dan silabus pembelajaran yang harus dipenuhi oleh peserta didik pada jenjang dan jenis pendidikan tertentu. ${ }^{13 k e t i g a ; ~ S t a n d a r ~ P r o s e s ~ m e l i p u t i ~ s t a n d a r ~}$ nasioanal yang berkaitan dengan pelaksanaan pembelajaran pada satu kesatuan pendidikan untuk mencapai standar kompetensi lulusan. ${ }^{14}$

Keempat; Standar Pendidik dan Tenaga Kependidikan meliputi kriteria prajabatan dan kelayakan fisik maupun mental, serta pendidikan dalam jabatan. ${ }^{15}$ Kelima; Standar Sarana dan Prasarana meliputi standar nasional pendidikan yang berkaitan dengan kriteria minimal tentang ruang belajar, tempat beribadah, tempat berolah raga, perpustakaan, laboratorium, bengkel kerja, tempat bermain dan tempat berekreasi serta sumber lain yang menunjang pembelajaran termasuk penggunaan teknologi informasi dan komunikasi. ${ }^{16}$ Keenam; Standar Pengelolaan untuk satuan pendidikan dasar dan menengah adalah standar pengelolaan pendidikan untuk sekolah / madrasah yang berkaitan dengan perencanaan, pelaksanaan dan pengawasan kegiatan pendidikan agar tercapai efisiensi dan afektivitas

12 Peraturan Pemerintah Nomor 32 Tahun 2013,Standar Kompetensi Lulusan, Pasal 1, ayat (5).

13 Peraturan Pemerintah Nomor 32 Tahun 2013, Standar Isi, Pasal 1, ayat(6)

14 Peraturan Pemerintah Nomor 32 Tahun 2013, Standar Proses, Pasal 1, ayat (7)

15Peraturan Pemerintah Nomor 32 Tahun 2013, Standar Pendidik dan Tenaga Kependidikan, Pasal 1, ayat (8)

16 Peraturan Pemerintah Nomor 32 Tahun 2013,Standar Sarana dan Prasarana, Pasal 1, ayat (9). 
Jurnal manajemen dan budaya STAI Darul Kamal NW Kembang kerang

Volume 1 No 2 Tahun 2021

P-ISSN : 2775-1643

E-ISSN : 2774-6704

https://journal.staidk.ac.id/index.php/manajemenbudaya

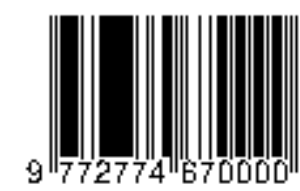

penyelenggaraan pendidikan. ${ }^{17}$ Ketujuh; Standar Pembiayaan meliputi standar yang mengatur komponen dan biaya operasi yang berlaku selama satu tahun. ${ }^{18}$ Ketujuh; Standar Penilaian meliputi kriteria mengenai mekanisme, prosedur dan instrumen penilaian hasil belajar peserta didik. ${ }^{19}$ kedelapan; Akreditasi merupakan proses penilaian dengan indikator tertentu berbasis fakta. Asesor melakukan pengamatan dan penilaian sesuai dengan realitas, tanpa ada manipulasi. ${ }^{20}$

\section{Metode Penelitian}

Penelitian ini termasuk ke dalam jenis penelitian lapangan (field research) dengan pendekatan kualitatif yaitu penelitian yang menekankan analisisnya pada proses penyimpulan induktif serta pada analisis terhadap dinamika hubungan antar fenomena yang diamati dan dengan menggunakan logika ilmiah. ${ }^{21}$ Sehingga dalam penelitian ini peneliti mencoba menganalisis pengelolaan lembaga Pendidikan Islam yang berorientasi pada mutu pendidikan pesantren. Penelitian dilakukan dengan cara menganalisis buku-buku, hasil penelitian yang sudah dipublikasikan dan kepala sekolah, wakil kepala bidang manajemen mutu, guru-guru yang mengetahui, memahami, dan mengalami proses pengelolaan mutu pendidikan di MA Sunan Pandanaran untuk mengetahui lebih mendalam mengenai konsep manajemen lembaga pendidikan berorientasi pada mutu.

Teknik pengumpulan data dapat dilakukan dengan Observasi (pengamatan), Interview (wawancara), dan Dokumentasi Gabungan ketiganya. ${ }^{22}$ Melalui observasi ini peneliti akan melakukan pengamatan di MA Sunan Pandanaran dan mencatat setiap detail kejadian secara singkat, padat, dan jelas. Selain itu, melalui metode observasi pula peneliti memperoleh data tentang gambaran manajemen lembaga pendidikan yang berorientasi pada mutu yang diterapkan di MA Sunan Pandanaran.

17Peraturan Pemerintah Nomor 32 Tahun 2013,Standar Pengelolaan, Pasal 1, ayat (10).

18 Peraturan Pemerintah Nomor 32 Tahun 2013, Standar Pembiayaan, Pasal 1, ayat (11)

19 Peraturan Pemerintah Nomor 32 Tahun 2013, Standar Penilaian,Pasal 1, ayat (12)

20 Jamal Ma'mur Asmani, Tips Praktis Membangun dan Mengolah Administrasi Sekolah, (Yogyakarta: Diva Press, 2011).

21 Nana Syaodih Sukmadinata, Metode Penelitian Pendidikan, (Bandung: Remaja Rosdakarya, 2013).

${ }^{22}$ Sugiyono, Metode Penelitian Pendidikan, (Bandung: Alfabeta, Cet Ke-18, 2013). 
Jurnal manajemen dan budaya STAI Darul Kamal NW Kembang kerang

Volume 1 No 2 Tahun 2021

P-ISSN : 2775-1643

E-ISSN : 2774-6704

https://journal.staidk.ac.id/index.php/manajemenbudaya

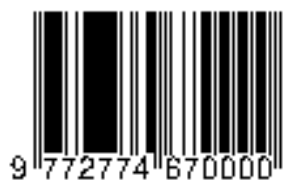

Peneliti akan melakukan wawancara terhadap subjek penelitian dengan cara mengajukan beberapa pertanyaan dengan pedoman tertentu yang telah dipersiapkan terlebih dahulu. Sedangkan dokmentasi untuk memperoleh data tentang keadaan MA Sunan Pandanaran berupa dokumen tertulis tentang Akreditasi, manajemen mutu, berkas/surat, foto-foto kegiatan, dan administrasi MA Sunan Pandanaran yang menunjang hasil penelitian kualitatif.

Teknik analisis data adalah proses mencari dan menyusun secara sistematis data yang diperoleh dari hasil wawancara, catatan lapangan, dan dokumentasi, dengan cara mengorganisasikan data, menjabarkannya ke dalam unit-unit, melakukan sintesa, menyusun ke dalam pola, memilih mana yang penting dan yang akan dipelajari, dan membuat kesimpulan yang dapat dipahami oleh diri sendiri maupun orang lain. ${ }^{23}$ Analisis data dalam penelitian kualitatif dimulai dengan menyiapkan dan mengorganisasikan data (yaitu, data teks seperti transkip, atau data gambar ssperti foto) untuk analisis, kemudian mereduksi data tersebut menjadi tema melalui proses pengodean dan peringkasan kode, dan terakhir menyajikan data dalam bentuk bagan, tabel, atau pembahasan. ${ }^{24}$

\section{Pembahasan}

\section{Perencanaan pendidikan di MA Sunan Pandanaran}

Perencanaan yang menjadi awal dari sebuah kegiatan sangat menentukan terhadap perkembangan lembaga pendidikan, husunya lembaga pendidikan yang mampu mencapai Akreditasi A tentunya mengadakan perencaan dengan sangat matang. Perencanaan pendidikan agar tercapainya sasaran mutu yang diinginkan, MA Sunan Pandanaran sebagaimana Ainun Hakiemah sebagai kepala sekolah MA Sunan Pandanaran mengungkapkan bahwa langkah-langkah menyusun perencanaan peningkatan mutu lulusan di MA Pandanaran dilakukan dengan penyusunan program kerja MA Sunan Pandanaran dan penyusunan kurikulum MA Sunan Pandanaran yang melibatkan partisipasi aktif dan dinamis dari semua stekholder

23 Sugiyono, Metode Penelitian Pendidikan, (Bandung: Alfabeta, Cet ke-21, 2015).

24 John W. Creswell, Penelitian Kualitatif $\mathcal{E}$ Desain Riset; Memilih Di Antara Lima Pendekatan, (Yogyakarta: Pustaka Pelajar, 2015). 
Jurnal manajemen dan budaya STAI Darul Kamal NW Kembang kerang

Volume 1 No 2 Tahun 2021

P-ISSN : 2775-1643

E-ISSN : 2774-6704

https://journal.staidk.ac.id/index.php/manajemenbudaya

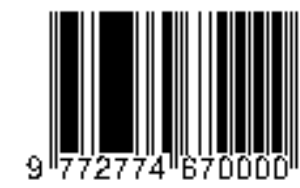

yang ada di MA Sunan Pandanaran, yaitu kepala sekolah, wakil-wakil kepala sekolah, guru, tenaga tata usaha, orang tua siswa dan bahkan siswa dan staf lainnya termasuk institusi yang memiliki kepedulian terhadap pendidikan di MA Sunan Pandanaran". 25

\section{Sistem organisasi melaksanakan perencanaan pendidikan.}

Dalam perencanaan pendidikan MA Sunan Pandanaran melibatkan seluruh fungsi kerja dari setiap unit kerja di dalam Madrasah. ${ }^{26}$ Seperti: Pertama, Komite Madrasah berfungsi mendorong tumbuhnya perhatian dan komitmen masyarakat terhadap penyelenggaraan pendidikan yang bermutu, melakukan kerja sama dengan masyarakat dan pemerintah berkenaan dengan penyelenggaraan pendidikan yang bermutu, menampung dan menganalisis aspirasi, ide, tuntutan, dan berbagai kebutuhan pendidikan yang diajukan oleh masyarakat, memberikan masukan, pertimbangan, dan rekomendasi kepada satuan pendidikan mengenai; 1) Kebijakan dan Program Pendidikan, 2) Kriteria Kinerja Satuan Pendidikan, 3) Kriteria Tenaga Kependidikan, 4) Kriteria Fasilitas Pendidikan, 5) Hal-hal lain yang terkait dengan penyelenggara pendidikan, dan mendorong orang tua dan masyarakat dalam rangka pembiayaan penyelenggaraan pendidikan di satuan pendidikan, serta melakukan evaluasi dan pengawasan terhadap kebijakan, program, dan penyelenggaraan di satuan pendidikan.

Kedua, Kepala Madrasah yang Bertugas sebagai edukator, manajer administrator, dan supervisor, pemimpin atau leader inovator montivator, ketiga; Waka kurikulum yang bertugas untuk menyusun dan menjabarkan kalender pendidikan, menyusun pembagian tugas guru dan jadwal pelajaran, mengatur penyusunan program pengajaran (program semester), program satuan pelajaran dan persiapan mengajar, serta penjabaran dan penyesuaian kurikulum, mengatur pelaksanaan kurikuler dan ekstra kurikuler, mengatur pelaksanaan program penilaian kriteria kenaikan kelas, kriteria kelulusan, dan laporan kemajuan belajar

25 Wawancara dengan Hj. Ainun Hakiemah, 27-11-2018

26 Dokumentasi, Rencana Kerja Jangka Menengah (RKJM) MA Sunan Pandaran, 2018- 
Jurnal manajemen dan budaya STAI Darul Kamal NW Kembang kerang

Volume 1 No 2 Tahun 2021

P-ISSN : 2775-1643

E-ISSN : 2774-6704

https://journal.staidk.ac.id/index.php/manajemenbudaya

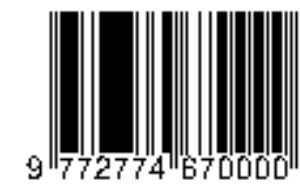

siswa, serta pembagian rapot dan sttb, mengatur pelaksanaan program perbaikan dan pengajaran, mengatur pemanfaatan lingkungan sebagai sumber belajar, mengatur pengembangan mgmp dan koordinator mata pelajaran, mengatur mutasi siswa, melakukan supervisi, administrasi, dan akademis, serta menyusun laporan.

Ketiga; Waka Kesiswaan dengan tugas mengatur program pelaksanaan bimbingan dan konseling, mengatur dan mengkoordinasikan pelaksanaan 7K (keamanan, ketertiban, kebersihan, keindahan, kekeluargaan, kesehatan, kerindangan), mengatur dan membina kegiatan OSIS, menyusun dan mengatur siswa teladan madrasah, menyelenggarakan cerdas cermat dan olah raga prestasi, dan menyeleksi calon untuk diusulkan mendapatkan beasiswa

Keempat; Waka Madin dan Tahfidz bertugas untuk melaksanakan kegiatan Madrasah Diniyah secara terstruktur, melaksanakan program tahfidz berjenjang, mengadakan kelas unggulan tahfidz, mengadakan kelas unggulan kitab, melaksanakan ujian Madin dan Tahfidz pada setiap tri wulan, membuat laporan penilaian Madin dan Tahfidz

Kelima; Waka Sarana dan prasana bertugas untuk merencanakan kebutuhan prasarana untuk keperluan PBM, merencanakan program pengadaannya, mengatur pemanfaatan sarpras, mengelola perawatan, perbaikan dan pengisian, mengatur pembukuannya, dan menyusun laporan

Keenam; hubungan masyarakat bertugas untuk mengatur dan mengembangkan hubungan dengan komite madrasah dan peran komite madrasah, menyelenggarakan baksos dan karyawisata, menyelenggarakan pameran hasil pendidikan madrasah (gebyar madrasah), dan menyusun laporan

Keenam; Tenaga Kependidikan seperti Kepala tata usaha sekolah mempunyai tugas melaksanakan Ketatausahaan sekolah dan bertanggung jawab kepada kepada sekolah dalam kegiatan-kegiatan sebagai berikut : Penyusunan program kerja tata usaha sekolah, Pengurusan administrasi ketenagaan dan siswa, Penyusunan administrasi perlengkapan sekolah, Penyusunan dan penyajian data/ statistik 
Jurnal manajemen dan budaya STAI Darul Kamal NW Kembang kerang

Volume 1 No 2 Tahun 2021

P-ISSN : 2775-1643

E-ISSN : 2774-6704

https://journal.staidk.ac.id/index.php/manajemenbudaya

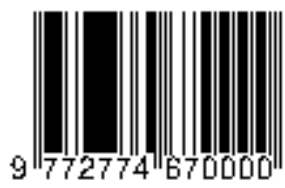

sekolah, Mengkoordinasi dan melaksanakan 7K, Penyusunan laporan pelaksanaan kegiatan pengurusan Ketatausahaan secara berkala27

\section{Sistem manajemen kendali mutu terhadap pelaksanaan pendidikan}

Sistem pengendalian mutu di MA Sunan Pandanaran dilakukan melalui manajemen sumber daya manusia sebagaimanana yang dijelaskan oleh ibu Ainun Hakiemah bahwa Sistem pengendalian mutu melalui manajemen sumber daya manusia dilakukan dengan beragam strategi, kebijakan dan program, mulai dari analisis kebutuhan, proses rekrutmen, seleksi dan penempatan, pelatihan dan pengembangan, penilaian kinerja hingga pemberian kompensasi".

Upaya ini dilakukan untuk menjaga ketersediaan Sumber Daya Manusia (SDM) berkualitas, professional dan berintegritas didalam lembaga. Fungsi manajemen sumber daya manusia di madrasah ini diwenangkan pada bagian direksi, dan berkoordinasi dengan kepala madrasah dalam operasionalnya. Adapun terkait pengambilan keputusan tetap menjadi kebijakan yayasan. Ainun Hakiemah sebagai kepala sekolah menjelaskan bahwa dalam meningkatkan wawasan, kemampuan dan pengalaman para Sumber Daya Manusia atau warga madrasah, kami memberikan fasilitas pelatihan dan pengembangan karir, yang juga ditunjang dengan beragam macam pembinaan. Madrasah ini memiliki Teacher Training Centeryang menyelenggarakan program pelatihan untuk guru secara internal".

Para tenaga pendidik dan kependidikan juga didukung penuh oleh yayasan Pondok Pesantren Sunan Pandanaran untuk mengikuti berbagai macam pelatihan dan seminar yang diadakan organisasi di luar sekolah, baik yang berskala nasional hingga internasional. Pengembangan karir para SDM dilakukan dengan kebijakan promosi untuk mereka yang memiliki kinerja baik, sebaliknya kebijakan mutasi akan diberikan bagi mereka yang terlihat mengalami penurunan kinerja.

Dalam menunjang hal tersebut, ada beberapa kegiatan yang di lakukan oleh MA sunan pandanara yaitu: 1) Mengadakan breafinng pagi sebelum masuk ke kelas jam pertama, 2) Setiap akhir bulan mengadakan evaluasi kurikulum pembelajaran, 3)

27 Dokumentasi, Rencana Kerja Jangka Menengah (RKJM) MA Sunan Pandaran, 2018- 
Jurnal manajemen dan budaya STAI Darul Kamal NW Kembang kerang

Volume 1 No 2 Tahun 2021

P-ISSN : 2775-1643

E-ISSN : 2774-6704

https://journal.staidk.ac.id/index.php/manajemenbudaya

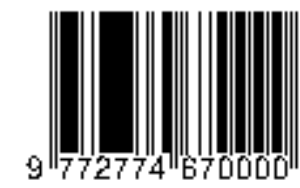

Wali kelas, tenaga pendidik, guru mapel melakukan evaluasi sikap dan pengetahuan peserta didik.

\section{Sistem penjaminan mutu diterapkan}

Lembaga pendidikan MA Sunan Pandanaran memiliki sistem penjaminan mutu yaitu terakreditasi A oleh BAN-S/M. Ini merupakan upaya yang di lakukan oleh MA sunan pandanaran dengan tercapainya 8 SNP yang telah ditetapkan dengan nilai 97.

Sesuai dengan visi dan misi yang di kemukakan di awal, dan dengan pencapian 8 standar nasional pendidikan mengantarkan MA Sunan Pandanaran menjadi lembaga pendidikan yang bermutu dan semua sudah tertuang dalam hasil evaluasi diri MA Sunan Pandanaran.

\section{Sistem evaluasi terhadap penyelenggaran pendidikan}

Dalam sistem evaluasi di MASPA terhadap penyelenggaraan pendidikan yang bermutu ada beberapa mekanisme yang dilakukan, yaitu: 28

Pertama: program monitoring dan evaluasi; menusun rencana monitoring untuk setiap kegiatan, melaksanakan monitoring dan evaluasi penyelenggaraan pendidikan, menyusun laporan, tindak lanjut monitoring dan evaluasi

Kedua: Tujuan Monitoring dan Evaluasi; Monitoring dilakukan untuk mengetahui apakah program sekolah berjalan sesuai dengan yang direncanakan. Selain itu juga untuk mengetahui hambatan-hambatan yang terjadi dan cara mengatasinya. Hasil monitoring digunakan untuk menyempurnakan pelaksanaan program sekolah.

Evaluasi bertujuan untuk mengetahui apakah program sekolah yang telah ditetapkan telah mencapai sasaran yang diharapkan. Hasil evaluasi digunakan untuk mengambil keputusan tentang program sekolah secara utuh, mulai dari kesesuaian dengan kebutuhan, tuntutan kebutuhan, tuntutan masa depan, input, proses dan output yang diharapkan.

${ }^{28}$ Dokumentasi, Rencana Kerja Jangka Menengah (RKJM) MA Sunan Pandaran, 2018- 
Jurnal manajemen dan budaya STAI Darul Kamal NW Kembang kerang

Volume 1 No 2 Tahun 2021

P-ISSN : 2775-1643

E-ISSN : 2774-6704

https://journal.staidk.ac.id/index.php/manajemenbudaya

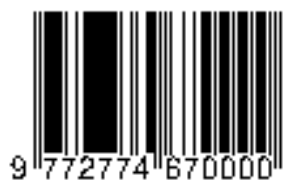

Ketiga: Waktu Pelaksanaan Monitoring dan Evaluasi serta Petugas melibatkan tim pengembang Madrasah melaksanakan Monev Setiap Bulan, dan Tim pengembang Madrasah menyusun Laporan Hasil Monev

Keempat: Pemanfaatan Hasil Monitoring dan Evaluasi serta Tindak Lanjut dengan mencermati hasil monitoring dan evaluasi dapat diidentifikasi berbagai hambatan dan kemajuan pelaksanaan program sekolah, Kepala sekolah menggunakan hasil monitoring dan evaluasi sebagai acuan dalam melakukan pembinaan terhadap guru dan karyawan, Hasil monitoring dan evaluasi digunakan sebagai dasar penyusunan program sekolah yang akan datang, Laporan monitoring dan evaluasi yang disusun oleh sekolah digunakan juga sebagai laporan kemajuan dan akuntabilitas sekolah kepada masyarakat dan lembaga terkait

Strategi pengembangan pendidikan dan peningkatan mutu terhadap pelaksanaan pendidikan

Dalam pengembangan pendidikan dan peningkatan mutu terhadap pelaksanan pendidikan dapat di lihat dari Matriks program strategis berikut:29

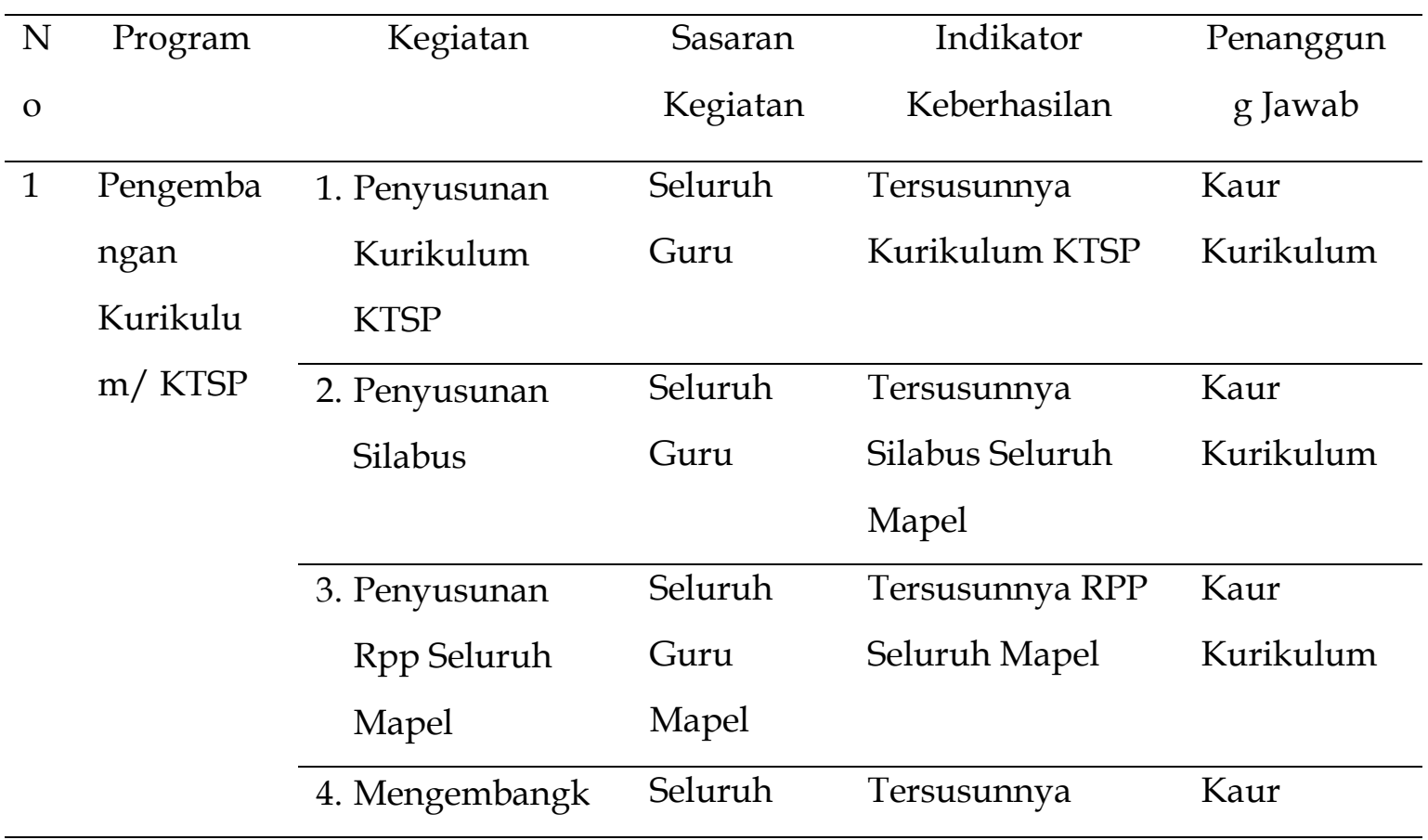

${ }^{29}$ Dokumentasi, Rencana Kerja Jangka Menengah (RKJM) MA Sunan Pandaran, 2018- 


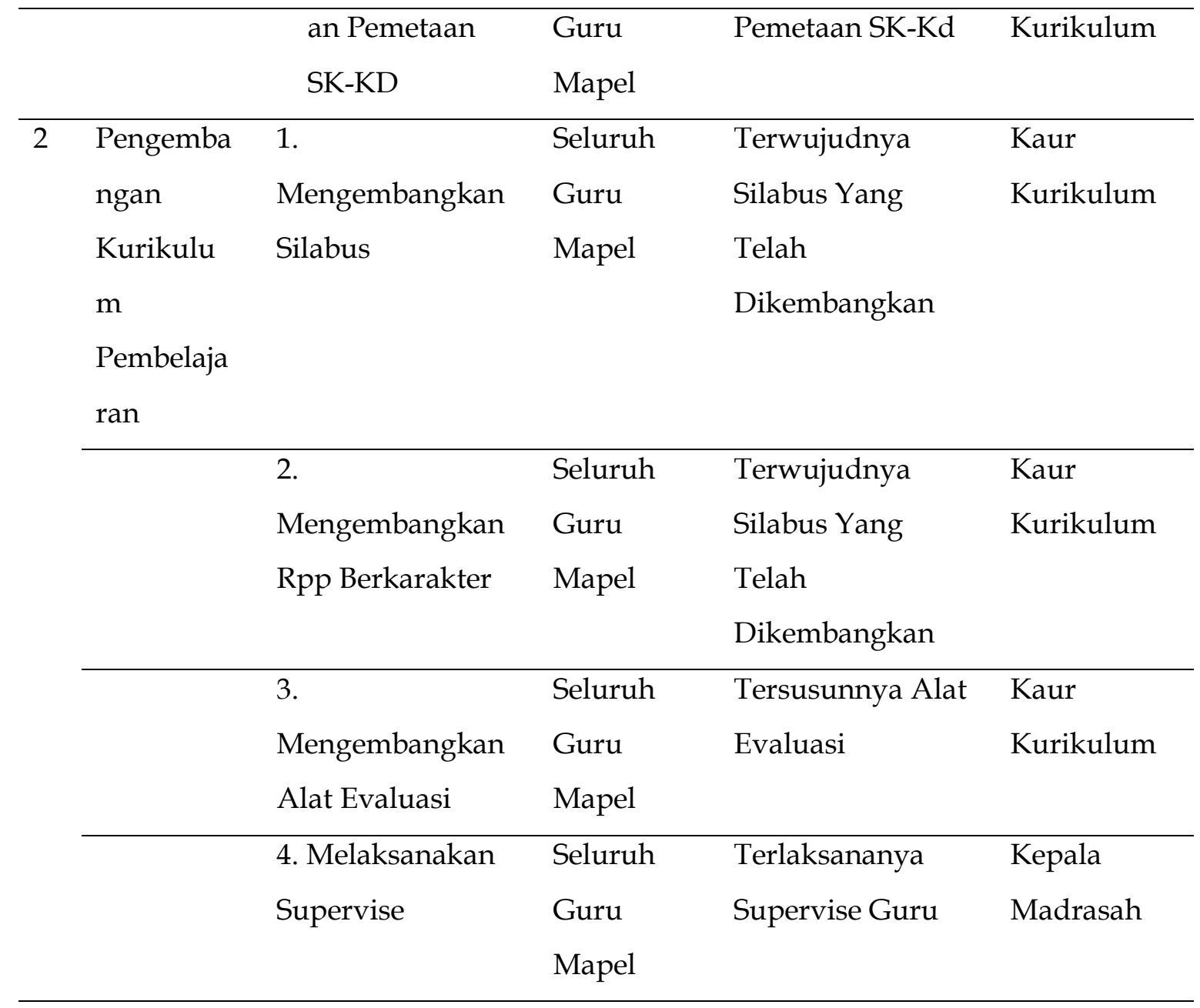

Pokok-pokok pengembangan sarana dan prasarana meliputi tersedianya sarana dan prasarana pendidikan baik secara kualitas maupun kuantitas yang memadai dengan melakukan kerjasama dengan pihak lain dalam : Rehab ruang kelas, Pengadaan sarana kelas, Mengembangkan peralatan laboratorium komputer dan keterampilan, Mengembangkan dan inovasi media pembelajaran untuk semua mata pelajaran, Pengadaan alat olahraga, Mengembangkan peralatan laboratorium IPA, Mengembangkan peralatan laboratorium Bahasa, Mengembangkan dan inovasi pusat-pusat sumber belajar, Mengembangkan sarana dan prasarana serta inovasi perustakaan, Mengembangkan sarana dan prasarana tempat ibadah, Mengembangkan sarana dan prasarana Bimbingan dan Konseling. 
Kesadaran terhadap pembiayaan pendidikan sebagai penujang peningkatan mutu pendidikan dapat dilihat dari tabel di bawah ini:

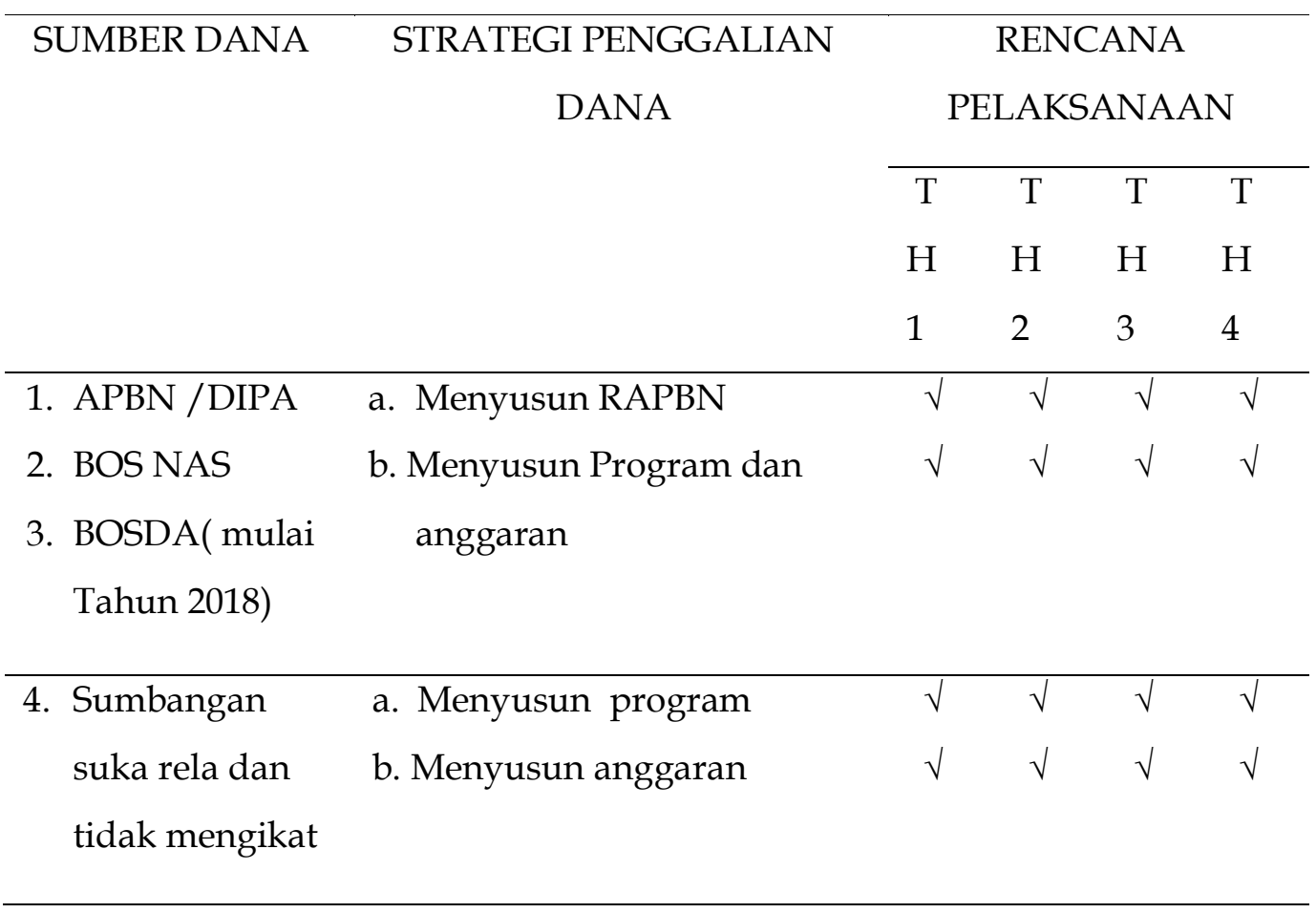

\section{Kesimpulan}

Berdasarkan hasil penelitian yang telah penulis lakukan tentang Manajemen Lembaga Pendidikan Berorientasi Pada Mutu di pada MA Sunan Pandanaran, dapat diambil kesimpulan sebagai berikut: Perencanaan pendidikan di MA Sunan pandanaran dengan melibatkan seluruh SDM yang kemudian menetapkan Rumusan visi yang empat yaitu mandiri, berprestasi, cerdas, berkepribadian qur'ani. Sistem organisasi dalam melaksnakan perencanaan pendidikan yaitu dengan melibatkan seluruh unit kerja dengan tugas tugas yang telah di tetapkan, unit kerja tersebut adalah: komite madrasah, kepala madrasah, waka kurikulum, waka kesiswaan, waka madin dan tahfiz, waka sarana dan prasarana, hubungan masyarakat, tenaga kependidikan.

Sistem pengendalian mutu MA sunan pandanaran dilakukan melalui Sumber Daya Manusia dengan mengadakan Teaching training center dan ada beberapa kegiatan 
Jurnal manajemen dan budaya STAI Darul Kamal NW Kembang kerang

Volume 1 No 2 Tahun 2021

P-ISSN : 2775-1643

E-ISSN : 2774-6704

https://journal.staidk.ac.id/index.php/manajemenbudaya

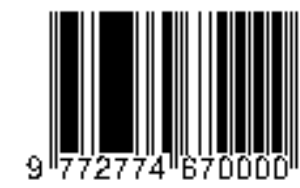

yang di lakukandalam sistem pengendalian mutu, yaitu: Mengadakan breffing pagi sebelum masuk ke kelas jam pertama, Setiap akhir bulan mengadakan evaluasi kurikulum pembelajaran, Wali kelas, tenaga pendidik, guru mapel melakukan evaluasi sikap dan pengetahuan peserta didik.

Sistem evaluasi MA Sunan pandanaran yaitu ada beberapa mekanisme yang dilakukan yaitu dari program monitoring dan evaluasi yang menyangkut: penyusunan rencana monitoring untuk setiap kegiatan, Melaksanakan monitoring dan evaluasi penyelenggaraan pendidikan, Menyusun Laporan, Tindak Lanjut Monitoring dan Evaluasi.

\section{Daftar Referensi}

Asmani, Jamal Ma'mur, Tips Praktis Membangun dan Mengolah Administrasi Sekolah (Yogyakarta: Diva Press, 2011)

Suryobroto, B., Manajemen Pendidikan di Sekolah (Jakarta: Rineka Cipta, 2004)

Danim, Sudarwan, Visi Baru Manajemen Sekolah (Dari Unit Birokrasi ke Lembaga Akademik) (Jakarta: PT Bumi Aksara, 2006)

Departemen Agama, Pedoman Akreditasi Madrasah (Jakarta: Dirjen Kelembagaan Islam, 2005)

Dokumentasi, Rencana Kerja Jangka Menengah (RKJM) MA Sunan Pandaran, 20182021.

Kuncoro, E. A., dalam Buchori Alma (ed), Manajemen Coorporate Strategi Pemasaran Jasa Pendidikan : Fokus Mutu dan Layanan Prima (Bandung, Alfabeta, 2008)

Engkoswara dan Komariah, A., Administrasi Pendidikan (Bandung: Alfabeta , 2010)

Gaspersz, Vincent, Total Quality Management (Jakarta: PT Gramedia Pustaka Utama, 2001)

John W. Creswell, Penelitian Kualitatif \& Desain Riset; Memilih Di Antara Lima Pendekatan (Yogyakarta: Pustaka Pelajar, 2015)

Komariyah, Aan dan Cepi Triatna, Visonary Leadership; Menuju Sekolah Efektif (Jakarta: Bumi Aksara, 2008) 
Jurnal manajemen dan budaya STAI Darul Kamal NW Kembang kerang

Volume 1 No 2 Tahun 2021

P-ISSN : 2775-1643

E-ISSN : 2774-6704

https://journal.staidk.ac.id/index.php/manajemenbudaya

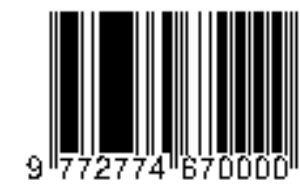

Nanang Fattah, Sistem Penjaminan Mutu Pendidikan (Bandung: Remaja Rosda Karya, 2012)

Peraturan Pemerintah Nomor 32 Tahun 2013, Standar Isi, Pasal 1, ayat(6)

Peraturan Pemerintah Nomor 32 Tahun 2013, Standar Pembiayaan, Pasal 1, ayat (11)

Peraturan Pemerintah Nomor 32 Tahun 2013, Standar Pendidik dan Tenaga Kependidikan, Pasal 1, ayat (8)

Peraturan Pemerintah Nomor 32 Tahun 2013, Standar Penilaian,Pasal 1, ayat (12)

Peraturan Pemerintah Nomor 32 Tahun 2013, Standar Proses, Pasal 1, ayat (7)

Peraturan Pemerintah Nomor 32 Tahun 2013,Standar Kompetensi Lulusan, Pasal 1, ayat (5).

Peraturan Pemerintah Nomor 32 Tahun 2013,Standar Sarana dan Prasarana, Pasal 1, ayat (9).

Prihatin, Eka, Teori Administrasi Pendidikan (Bandung: Alfabeta, 2011)

Ravik Karsidi, Peningkatan Mutu Pendidikan Melalui Penerapan Teknologi Belajar Jarak Jauh, Makalah Disampaikan dalam Seminar Regional Unit Pelaksana Belajar Jarak Jauh - Universitas Terbuka, Solo: 28 Mei 2005.

Sagala, Syaiful, Manajemen Mutu Terpadu dalam Pendidikan; Konsep, Strategi dan Aplikasi (Jakarta: PT Grasindo, 2002)

Sudarwan Danim, Agenda Pembaruan Sistem Pendidikan (Yogyakarta: Pustaka Pelajar, 2003)

Sugiyono, Metode Penelitian Pendidikan (Bandung: Alfabeta, 2015)

Sukmadinata, dan Syaodih, N., Metode Penelitian Pendidikan, (Bandung: Remaja Rosdakarya, 2013)

Usman, Husaini, Manajemen: Teori, Praktik, dan Reset Pendidikan (Jakarta: Bumi Aksara, 2009) 